\title{
Double standards on dress code and lust in the guise of tradition in the novel Umshado [Marriage], 2006, by N. Zulu: A feminist approach
}

\begin{tabular}{|c|c|}
\hline \multicolumn{2}{|c|}{$\begin{array}{l}\text { Authors: } \\
\text { Henry Gumede }{ }^{1} \text { @ } \\
\text { Nhlanhla Mathonsi }{ }^{1} \text { @ }\end{array}$} \\
\hline \multicolumn{2}{|c|}{$\begin{array}{l}\text { Affiliations: } \\
\text { 'Department of African } \\
\text { Languages, School of Arts, } \\
\text { College of Humanities, } \\
\text { University of KwaZulu-Natal, } \\
\text { Durban, South Africa }\end{array}$} \\
\hline \multicolumn{2}{|c|}{$\begin{array}{l}\text { Corresponding author: } \\
\text { Henry Gumede, } \\
\text { gumedeh@ukzn.ac.za }\end{array}$} \\
\hline \multicolumn{2}{|c|}{$\begin{array}{l}\text { Accepted: } 30 \text { Aug. } 2019 \\
\text { Published: } 06 \text { Dec. } 2019\end{array}$} \\
\hline \multicolumn{2}{|c|}{$\begin{array}{l}\text { How to cite this article: } \\
\text { Gumede, H. \& Mathonsi, N., } \\
\text { 2019, 'Double standards on } \\
\text { dress code and lust in the } \\
\text { guise of tradition in the novel } \\
\text { Umshado [Marriage], 2006, } \\
\text { by N. Zulu: A feminist } \\
\text { approach', Literator 40(1), } \\
\text { a1593. https://doi.org/ } \\
\text { 10.4102/lit.v40i1.1593 }\end{array}$} \\
\hline \multicolumn{2}{|c|}{$\begin{array}{l}\text { Copyright: } \\
\text { (c) 2019. The Authors. } \\
\text { Licensee: AOSIS. This wo } \\
\text { is licensed under the } \\
\text { Creative Commons } \\
\text { Attribution License. }\end{array}$} \\
\hline \multicolumn{2}{|c|}{ Read online: } \\
\hline 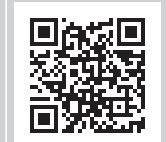 & $\begin{array}{l}\text { Scan this QR } \\
\text { code with your } \\
\text { smart phone or } \\
\text { mobile device } \\
\text { to read online. }\end{array}$ \\
\hline
\end{tabular}

This article critically reviews the differences in attitudes and in language used between men and women through dialogue, especially when it comes to dress code, and with specific reference to N. Zulu's novel Umshado. The various dresses worn by the protagonist, Tholakele, during her encounters with Bhekani portray her as a loose woman who always wishes to seduce men, and as one who is sexually available to men. But all that Tholakele seems to demand is that she should be allowed to dress in any attire she feels comfortable in, and to behave freely, as men do. She represents women who wish to introduce change, and who aspire to be placed on the same pedestal as their male counterparts. The novel, however, shows that women are chastised and ostracised when they try to break free from the shackles of patriarchy. Hence, we argue in this article that the juxtaposition of Tholakele's behaviour, so disapproved of by the society, and that of Bhekani's behaviour, shows double standards in the treatment of men and women.

Keywords: widowhood; feminism; gender; subversion of identity; womanism; patriarchy; gender stereotype; dress code; subaltern; double standards

\section{Introduction}

Several researchers have critically reviewed the negative portrayal of female characters in Zulu literary texts. Zuma (2009), for instance, in her study, 'Feminist analysis of the representation of female and male characters in selected plays in Ishashalazi', investigates the portrayal of female and male characters in two plays: Kwakuhle kwethu and Umninimuzi. The study investigates the role and images of women and men as presented in dramatised stories. It is worth noting that the book Ishashalazi is written by male authors, Mbhele and Ntuli (1988). The beliefs held by characters in these plays reflect the traditional lifestyle of the Zulu people (Gumede 2018:18). Zuma (2009) asserts that:

Many Zulu literary texts promote supremacy of men over women without being objective in questioning the legitimacy of the status quo in society. (p. 4)

Zuma's (2009) study focuses on character portrayal, the use of language, gender roles assigned to characters, the attitudes that are constructed and the influence of culture in establishing supremacy between the genders.

Masuku (2005), in her PhD thesis, 'Perceived oppression of women in Zulu folklore: A feminist critique', challenges the role and presentation of women in Zulu traditional literature. She investigates whether the perceived oppression of women is reflected in such Zulu folklore (Gumede 2018:29).

Zondi (2013) is one of the feminist critics who challenges male domination in Zulu literary works. In her article, 'The position of women in Zulu and Shona societies: The case of Uvalo Lwezinhlonzi and Nervous Conditions', Zondi (2013) challenges the issues of gender discrimination and patriarchal stereotypes in the portrayal of female characters in these two novels. The article explores oppressive practices commonly found in Zulu and Shona cultures, taking into account the voice of female and male authorship (Gumede 2018:21).

The language used by the author, N. Zulu, in the novel Umshado appears to support the retention of male domination, that women should always play a subordinate role or second fiddle to their male counterparts. 
Radical feminists believe that this patriarchal culture forms part of the 'micro-political structure' that helps to maintain the larger politico-economic structure (Thorne \& Henley 1976). 'The use of language shapes our understanding of the social world, our relationships to one another and our social identities' (Thorne \& Henley 1976:15). Many feminists further note that sexual identities reflect the material interests of both, those who have power and those who do not. Hence, this relationship between men and women is inextricably linked to the language that is used to describe female characters.

Zulu's novel Umshado is historically conditioned by a number of factors relating to public morals in a patriarchal society. It challenges human sexuality and the new outlook on women in society. It also explores some of the modern problems resulting from the 'liberated' approach to sexuality, as exemplified in Umshado. The author's portrayal of the protagonist, Tholakele's, behaviour, however, actively casts her in a negative light for the reader because she is a woman, whilst Bhekani's behaviour does not seem to warrant the same opprobrium or censure. This echoes an imbalance in the treatment of men and women in the Zulu society. Tholakele's behaviour is negatively perceived because she is a woman, as she strives for the role that would allow her to be free from traditional norms and restrictions. Whilst women were kept quasi-slaves by patriarchy, which imposed a strict control over their sexuality and reproductive faculty, they now want to break away and enjoy freedom in their dress code without any restrictions. What used to be 'open hunting season' only for men has now become possible for women as well, if they have the independence of character and the beauty and winning ways to attract men.

\section{Synopsis of the novel Umshado}

The novel Umshado (2006) is concerned with problems experienced by both men and women. The story revolves around the protagonist, the beautiful Tholakele. Tholakele has just lost her husband, and her brother-in-law, Bhatomu, is asked to take over the responsibilities of his late brother [ukungena]. Tholakele decides to run away from her inlaws. She goes to live in a shack in Nyawushane, where she gets involved in drug dealing after befriending people who sell and consume drugs. Tholakele's friend, Pamella, a lesbian, is the mastermind behind the selling of and dealing in drugs.

Bhekani's misfortunes are also worth highlighting. He has a recurring dream in which his father insists that he must get married. Bhekani is confused because his former lover, Lindiwe, has left him, and he has not been in contact with her for a long time. The pressure from his father in the dream forces him to find a girlfriend urgently. In the midst of his predicament, he falls in love with Tholakele, and immediately plans to marry her. Bhekani's father does not 'show' him in his dream which girl to marry; therefore, when Bhekani meets Tholakele, he is convinced that she is the one to marry. Bhekani's wish to marry Tholakele flies in the face of his mother's warning against marrying somebody who has been married before and who is a widow.

Bhekani's mother tells him that his father will never be happy if he marries such a person. Towards the end of the story, Bhekani's clothes are burnt at his home; he is robbed of his ilobolo money; and he is disgraced by the community when his fiancée Tholakele is arrested by the police on drug charges. This happens in the church during the wedding ceremony.

\section{Engaged theory}

It is important to define literary feminism briefly as this study is about the analysis of literary texts from a feminist perspective. Literary feminism refers to feminist criticism used in textual analysis to expose sexist assumptions. In literary feminism, great emphasis is placed on textual analysis, with the focus on sexist ideology. Cuddon (1991) defines feminist criticism in relation to literary feminism as follows:

Feminist criticism is an attempt to describe and interpret (and re-interpret) women's experience as depicted in various kinds of literature - especially the novels, and to a lesser extent, poetry and drama. (p. 338)

Literary feminism provides documentation that the traditional definitions do not cover, for example, that women suffer injustices because of their sex. Literary feminism does not deal with feminists themselves or provides a strategy for the reform of society; it silently extricates the feminist views found in fiction (Brown \& Olson 1992:82).

Pratt in Brown and Olson (1992:280) comments that feminism in fiction suggests a distinction between feminist fiction, 'narrowly defined as words in which the author's explicit intention is to expose some aspects of sexism', as stated in the preceding paragraph, and novels, which are 'unintentionally' feminist and of concern because of their place in the literature of women. The latter constitutes a fiction that includes careful exploration of women's existential situation within a carefully orchestrated treatment of other and broader human conflicts and relationships.

Ogunyemi (1985:64-65) contends that, for literature to be identified as feminist, it must not deal only with women's issues, but should also posit some aspects of feminist ideology in which a reader may expect to find a combination of literary themes, such as critical perceptions regarding the inequalities of sexism, a change leading to female victory in a feminist world, or a failure to eliminate sexism and, finally, a style characterised by acrimony of feminist discourse.

\section{The critique of the novel Umshado}

Gumede and Mathonsi (2019) have written about the problems associated with widowhood, highlighting that terms used, such as ukuzila [to mourn] and ukungena [forcing 
a widow to marry her late husband's brother], just to name a couple, imply a total lack of freedom of a widow. This article seeks to show that, in this community, even the colour and the length of the mourning dress are prescribed for widows.

\section{Dress code prescription and men's lust masked by tradition}

The colour of the dress prescribed for widows is usually black, and the prescribed length is that it should be below the knees. Tholakele's dress is black, but it is so short that Bhekani is able to see her thighs. The special meaning of the inzilo [mourning dress] that Tholakele wears on the death of her husband is questionable, because it is very short for a widow in mourning.

In the novel Umshado, a man's lust becomes evident. Bhekani is obsessed by what he sees - Tholakele's beautiful legs. His reaction to what he is seeing shows that women are described in terms of what is appreciated by men. In the extract below, the author offers this description (Zulu 2006):

Umoya ufune ukuphephula isiketi kuvele kancane iphezulu lamathanga. Anikine ikhanda uBhekani. Umqondo wakhe uvele usakhe usiqede sonke esingezansi sale ntokazi. [The wind almost blew up Tholakele's skirt, and he could partly see the upper part of her thighs. Bhekani shook his head. His mind just imagined the whole lower part of this woman's body.] (p. 2)

What Bhekani has just witnessed convinces him to court Tholakele. He eventually proposes, and she accepts him immediately without any waste of time. Scholes (1985), cited by Fuss (1989), has this to say:

We are subjects constructed by our experience and truly carry traces of that experience in our minds and on our bodies. Those of us who are male cannot deny this either. With the best will in the world we shall never read as women and perhaps not even like women. For me, born when I was born and living where I have lived, the very best I can do is to be conscious of the ground upon which I stand: to read not as but like a man. (p. 26)

The striking theme in the above quotation is the insistence on the socialisation of an individual. Society plays an important role in the socialisation of a person. This includes behaviour, the type of friends chosen and the language used.

Women's right to choose their dress code should not be seen as secondary to issues such as domestic violence and sexual abuse, as this in some way is connected to forms of gender oppression. Policing women's dress should be seen for what it really is - another means of controlling women's bodies. Saying what is or is not suitable clothing for women is a gender-based notion, which is not, however, applied to men.

Sifiso's comments about the way Tholakele is dressed when Bhekani sees her are very judgemental. Because of the dress she is wearing, she is deemed to have loose morals. Had it been a man dressed in a supposedly 'improper manner', he would not have been labelled negatively, as Tholakele is. Bhekani says (Zulu 2006):

Angisayiphathi eyethanga layo mfowethu, ngithe uma ngithi nhla kwagijima igazi ngokushesha. [I don't even want to talk about her thigh, my brother, when I took a glance at it, I had an adrenalin rush in my body.] (p. 3)

In the dialogue between Bhekani and Sifiso, his colleague, the latter asks him why Tholakele is dressed in such a manner that Bhekani is able to see her thighs (Zulu 2006):

Ubekhindeleni uze ubone amathanga nje? Sengathi akanasimilo nje lo muntu ombonile ndoda. [Why was she wearing a short dress that made you see her thighs? It looks like this person you saw has loose morals, man.] (p. 3)

Bhekani describes Tholakele's dress as more suited to a fashion show, and it is this dress which fires Bhekani's attraction to her, leading him to declare his love for her the first time he sees her. When Sifiso asks Bhekani whether Tholakele's short black dress is not for mourning, Bhekani quickly refutes the claim (Zulu 2006):

Leziya Sifiso ezomswenko nje, akusiyo inzilo. [Those ones, Sifiso, are for looking good, they are not for mourning.] (p. 3)

What women wear and where they wear it is a highly contested topic in patriarchal societies. In patriarchal societies, men are 'supposedly' allowed by culture to satisfy their lust, and this is evidenced by Dosekun's (2007) comments. Dosekun (2007:10) believes that a man's behaviour is loose, and that a man's enjoyment is sex, for which there are easy opportunities when he is out herding goats, away from home. Some men see women as sex objects who are there to satisfy their lust. Research shows that there was a practice in the Zulu tradition called ukusoma which men engaged in, to deal with the problem of lust. A woman was available to a man for this practice. Sexual gratification in this practice did not consider the woman's feelings - as long as the man was able to satisfy himself, this was considered acceptable. As noted by Von Kapff (2011:57), 'traditionally the sex game ukusoma (the type of sex that does not involve penetration) was practiced to alleviate sexual tension'. The author further reveals Bhekani's lust for Tholakele when he is touched by Tholakele's breast (Zulu 2006):

Wazizwa efudumala kancane uBheki ethintwa ibele likaTholi. [Bheki felt slightly warm when he was touched by Tholi's breast.] (p. 8)

The above extract reveals Bhekani's lust for Tholakele simply in the way he looks at her body - amabele [breasts], amathanga [thighs] and kanye nesingezansi [the lower part of her body]. It is the bodily features that seem to attract Bhekani the most. At this stage, one may assume that Bhekani is interested only in her physical attraction rather than in true love that may ultimately lead to marriage.

Some women wear very revealing dresses outlining the shape of the body, doing so either to attract men's attention or without realising how this might attract attention. Those who do this purposely do it because they know sex is a 
commodity that can be sold quickly to men who cannot control their lust. Bhekani's eyes are fully set on Tholakele's movement and apparel. She is wearing a revealing, short dress. The author says (Zulu 2006):

Ngale nkathi uTholi wayesusa izitsha zokuphuza ezibeka etafuleni, uBhekani elokhu embuka ehla enyuka. Le ngubo ekhanyayo yayisuke imgulise uBhekani. Isimo sikaTholakele yayisibeka obala. [During this time Tholi was taking the items that they were using to drink and putting them on the table. Bhekani kept his eyes on her as she was going up and down. This revealing dress was making Bhekani crazy. It was clearly showing how every part of Tholakele's body was shaped.] (p. 11)

When women are attacked for dressing 'inappropriately', they are blamed for these so-called acts of immorality. This only strengthens the belief that policing women's dress is the right thing to do. The way people dress can be an important expression of their religious, cultural or personal identity or beliefs. As a general rule, the right to freedom of religion or belief and freedom of expression entails that all people should be free to choose what - and what not - to wear. What women wear, and where, is highly contested by feminists. No one has a right to determine the dress code of another person, regardless of that person's sex. Women, therefore, should have the right to wear what they choose - be it traditional African attire, a miniskirt or pants - free from coercion. The see-through dress that Tholakele is wearing throws a killer punch on Bhekani. The author says (Zulu 2006):

Washeshe waqeda ukugqoka uTholi. Waphuma esegqoke ingutshana elulwelwesi elula, eyayikuveza konke ayekugqoke ngaphansi. [Tholi quickly finished dressing. She came out wearing a 'see-through' dress that was revealing everything that she was wearing underneath.] (p. 11)

Tholakele is portrayed as being interested in male companionship, which, in many instances, results in sexual intercourse. She appears not to be interested in marrying Bhekani, who is desperately looking for a wife. Bhekani's desperation is mainly influenced by his late father, who constantly reminds him (in his dream) to get married. Davies and Graves (1986) make the point that society also plays a role in the oppression of women:

First of all, we cannot only speak of women's oppression by men. In capitalist systems, women tend to be exploited by the very nature of society, particularly the working and peasant women, just as men are exploited. The difference is that women are hit particularly hard. Then you have forms of abuse that cut across class lines: sexual abuse, wife-beating, and the fact that men take advantage of the woman's role as a child-bearer. (p. 48)

The feminist writer Hooks (1991:31) believes that patriarchy may be seen as a ubiquitous male hierarchical ordering of society which is implemented in order to achieve and sustain political and social order. She argues that before 'we can resist male domination, we must break our attachment to sexism; we must work to transform female consciousness'. She contends that women, as an oppressed group, comply with their own subjugation by failing to examine their socialisation, hence maintaining the tradition.
Hooks (1991) also states that the authority of patriarchal ideology is such that:

It encourages women to believe that we are valueless and obtain value only by relating to or bonding with men. We are taught that our relationship with one another diminishes rather than enrich our experiences. We are taught that women are 'natural' enemies, that solidarity will never exist between us because we cannot, should not, and do not bond with one another. We have learned these lessons well. We must unlearn them ... We must learn to live and work in solidarity. We must learn the true meaning and value of sisterhood. (p. 29)

Many feminists such as Hooks (1991) believe that women need to recognise and celebrate their strengths and differences rather than allow themselves to be manipulated by divisive forces. What is stressed by Hooks (1991) is the value of differences as a basis for true sisterhood. Hooks (1991:38) sees feminism as 'politics, as a lifestyle, as something you become rather than something you do'. She believes that women need not share common oppression to overcome oppression. Obbo (1980) argues that:

Even though the world is changing all about women, it seems that woman's own attempts to cope with the new situations they find themselves in are regarded as a 'problem' by men, and a betrayal of traditions which are often confused with women's roles. Women must act as mediators between the present and the future. (p. 43)

According to patriarchal stereotype, Tholakele's behaviour is controversial, given her situation as someone who has recently lost her husband. People such as Tholakele represent women who are liberated from the societal norms that restrict their actions and their movements, and confine them to certain practices that are acceptable to a patriarchal society. Paradoxically, in spite of all this, Bhekani is madly in love with Tholakele, and he wants to make her his wife. Ogunyemi (1985) points out that:

For a novel to be identified as feminist, it must deal not only with women issues but it should also posit some aspects of a feminist ideology in which a reader can expect to find a combination of literary themes, such as critical perception of and reaction to patriarchy, sensitivity to the inequalities of sexism, a change leading to female victory in a feminist world, or a failure to eliminate sexism and finally, a style characterized by acrimony of a feminist discourse. (p. 65)

A man may be easily seduced by a woman's dress, and in many instances, this is a man's weakness. Man's weakness and selfishness, which they claim as a right given by their physiology, in many cases tend to spoil whatever they touch in nature, as revealed by the great amount of sexual abuse of women and children. In a situation where a man professes his love for a woman that he meets for the first time, and the woman accepts the man's advances immediately, it is that particular woman who is described in negative terms - isifebe [whore]. However, when this same behaviour comes from a male, he is shown in a positive light, using the term isoka [a male person with many girlfriends]. This act shows the double standards of the society with regard to the different treatment of women and men. 
The impression created by the above discussion is that some women are readily available to men. In patriarchal societies, Tholakele's behaviour is un-African because an African woman would initially pretend to refuse, just to bide her time, although she may show certain signs of affection. This is called ukubulala umbungu [to bide time] in Zulu. Tholakele here breaks the rules of the Zulu patriarchal tradition. If a man is allowed to make advances on a woman during their first encounter, the woman should be able to do the same. In a patriarchal society, a woman may even be scolded and accused of having loose morals when she openly shows her affection to her partner on their first encounter. In the dialogue between Sifiso and Bhekani, Sifiso is intrigued by Bhekani and Tholakele already dating after having only just met. Bhekani explains (Julu 2006):

Angeshelanga. Sabonisana. Sathola ukuthi siyathandana. Izimo zethu zazifana. Ushonelwe yindoda; ngifuna umakoti. [I did not court her. We shared ideas. We found that we are in love. Our situations were the same. She has lost her husband and I want a wife.] (p. 3)

Bhekani seemingly sees nothing wrong with Tholakele showing her affection at their first meeting. Tholakele believes in her own self-gratification, no matter what society says about her or her behaviour. Sifiso is, however, suspicious about how things have unfolded quickly between Tholakele and Bhekani.

The author seeks to depict Tholakele as a liberated woman representing women who flaunt their sexuality. Tholakele is not shy of revealing her sexual feelings when the occasion is suitable. She is a very 'open' and 'easy-going' person when it comes to expressing her sexual interests and desires. In the dialogue, when Bhekani asks where they can sit and talk, Tholakele immediately suggests that they go to her house so that they can talk and act without any interference. Tholakele says (Julu 2006):

Asiye kwami. Uzokhululeka lapho, akukho nkinga. [Let's go to my house. You will be free there, there is no problem.] (p. 7)

It is only their second meeting; and she is already showing signs that she would like them to make love. One may argue here that the author intentionally creates suspense for readers to arrive at various interpretations: some (readers) may think that women should not be readily available to men. The author creates further suspense by saying (Julu 2006):

UTholakele aqabule uBheki. Ethuke uBheki. 'Namuhla uyolala kwami Bheki'. [Tholakele kisses Bheki. Bheki is shocked. Today you are going to sleep at my place, Bheki.] (p. 26)

According to Zulu culture, Tholakele should not initiate the move so early and should have waited for Bhekani to take the initiative. For Bhekani, this is the first time he meets a girl of the type of Tholakele, who is not shy about displaying her feelings for him. In patriarchal societies, women are seen as inactive, because they cannot initiate the process of making love: only men are supposed to take the first step. Evidently, in a patriarchal society, men are hunters and women are the prey. Tholakele wants this reversed and equality achieved, and does not need any justification or approval from anybody.

The Zulu tradition expresses sexual conquests of women in terms of $u k u d l a$ [devouring]. This misconception creates the impression that women are commodities who provide sexual favours or pleasure for men. This commodification of women by men is prevalent in many patriarchal societies in which a man with many girlfriends becomes a 'hero' [isoka] because of his prowess and sexual conquests. When men go on dates with many different women, this is not frowned upon by society, simply because they are men. Such actions, in many instances, lead to sexual encounters with these women and may ultimately result in unplanned pregnancies. In such cases, men treat women as sex objects who are ready to be 'devoured' (-dliwa) by men, as is the case with Bhekani.

The Zulu family is patrilineal, with descent and property being transferred through the male line. The family is patriarchal, with the authority invested in the male household head. This common double standard allows men far greater sexual freedom than women. Within such an institution, particularly when the women have no employment outside the house, and no economic independence, women are the possessions (chattels) of their husbands and their objects of pleasure (Gray 2013:50). In patriarchal societies, men treat women as sex objects (victims of abuse). The postulation here is that men's behaviour is consistent with the way they are socialised in patriarchal societies. Society takes serious offence at seeing women of 'loose morals'; however, this stance does not extend to men. Negative stereotypes of women persist in spite of the backlash that women have to tolerate in order to bring societal change and development.

In many, if not all, patriarchal societies, there is always an imbalance of power in the treatment of men and women. For instance, it is accepted as normal for boys to behave in a certain way, whilst in similar conditions such behaviour for a girl would be deemed unacceptable. Feminists such as Young (1990) identify three main areas in which they (feminists) have conceptualised power: as a resource to be (re)distributed, as domination and as empowerment. Young (1990) shares the same idea with Butler (1990) as he does not view power as a resource or critical social good, but instead views it in relation to domination. Although feminists have used a variety of terms to refer to this kind of relationship including 'oppression', 'patriarchy', 'subjection', and so forth - the common thread in this analysis is an understanding of power not only as power over but also as a specific kind of power over a relationship, namely, one that is unjust or illegitimate.

Spivak (1988) cited in Fuss (1989:31) addresses the critique levelled against materialists, exposing and undermining the elitism which characterises South Asian culture and the 
failure to address questions of subjectivity adequately. Spivak (1988) argues that:

Subaltern [s]tudies deploy essentialism as a provisional gesture in order to align themselves with the very subjects who have been written out of conventional historiography. (p. 197)

What is strikingly different about Spivak's (1988) reading of Subaltern Studies is that she does not dismiss their essentialism as off the point. In fact, she reads the collective's humanist ambitions to locate a subaltern consciousness as a 'strategic use of positivist essentialism in a scrupulously visible political interest'. Her critique and endorsement of Subaltern Studies' essentialism suggests that humanism may be activated in the service of the subaltern; in other words, when put into practice by the dispossessed themselves, essentialism can be powerfully displacing and disruptive (Spivak 1988). Spivak's (1988) analysis speaks about the novel under discussion, Umshado, in which Bhekani uses his so-called masculine power to find his way to Tholakele.

Throughout the novel, language has been used to emphasise sexual differences between men and women.

In a similar vein, negative moral judgement is passed on a 'free-spirited' woman, Tholakele, who is judged as being a 'bad' woman. Tholakele's new 'free sex' morality, if permitted, would give women freedom to do what they wish, not requiring any commitment in return. However, the patriarchal society is not ready to accept this behaviour by women. Lorde (1984) feels that empowered women should not shy away from using their erotic powers. According to Lorde (1984), erotic autonomy observes that:

The erotic has often been misnamed by men and used against women. It has been made into the confused, the trivial, the psychotic, the plasticized sensation. For this reason, we have often turned away from the exploration and consideration of the erotic as a source of power and information, confusing [it] with its opposite, the pornographic. But pornography is a direct denial of power of the erotic, for it represents the suppression of true feeling. Pornography emphasizes sensation without feeling. (p. 54)

\section{Gender stereotypes}

Gender stereotypes about African women have been identified as one of the barriers for women achieving their full potential. Generally speaking, stereotypes against women are often based on preconceived notions of what women are assumed to be capable of, and this has been proved a fallacy. It is important to remember that gender has to be understood as a social rather than a physiological construction. By encouraging males to analyse their socially constructed gender profiles, it is possible to educate them on how their social roles may have an impact on gender equality. This will involve analysing the entrenchment of traditional male stereotypes in society and their consequent impact on women. Certain masculinities preserve and promote the inequalities experienced by men and women: in order to achieve gender equality, they must be dismantled.
Male stereotypes, in the context of gender inequality, do not operate in isolation. As De Beauviour (1949) puts it:

Thus humanity is male and man defines woman not in herself but as relative to him. She is not regarded as an autonomous being. She is defined and differentiated with reference to men and not he with reference to her; she is the subject; he is the absolute - she is the other, the object. (p. 26)

But Tholakele is an exception to this. She is not a common girl. Her happiness depends on her, and she does not wish to allow societal norms to dictate her how she must live her life.

Female characters are often treated more as symbols than as living, suffering individuals. Some researchers seem to identify undesirable qualities in modern women in terms of female-male relationships. In Umshado, Tholakele is characterised as a woman of doubtful virtue. Her actions are deemed undesirable in a male-dominated society. Tholakele's search for freedom brings her nothing but trouble because she is a woman.

Radical feminists believe that, for women to thrive and attain their freedom, they must be aggressive in their approach and fight for their autonomy.

In most Zulu literary works, depictions of female characters are from a fiercely male perspective, reflecting male conceptions of female sexuality. Some authors tend to overplay the sexuality of their female characters, creating the impression that women have no identity outside of their sexual roles. Such female characters usually serve to enhance the images of the male protagonists who occupy central positions in such literary works.

\section{Double standards}

This denotes that a principle is applied in different ways to different groups employed to treat them unfairly.

It is not a problem for Bhekani, for example, to have two girlfriends at the same time, as this appears to be the norm in African societies. Regarding this infidelity by Bhekani, the author simply reflects social custom, accepting it as more normal for boys to have greater independence than girls. Lindiwe, Bhekani's cheated girlfriend, is slowly realising that Bhekani is not really interested in her as he has already chosen another woman over her. It seems as though Lindiwe's mistake is her unwavering love for Bhekani. This shows Bhekani's calibre, as he is just one of the playboys who date girls in order to satisfy their sexual desires.

Double standards are therefore reflected in the treatment of males and females by a patriarchal society. Peterson and Runyan (1993) contend that:

... [T] he social construction of gender is actually a system of power that not only divides men and women as masculine and feminine, but typically also places men and masculinity above 
women and femininity and operates to value more highly those institutions and practices that are male dominated and/or representative of masculine traits and styles. (p. 21)

Bhekani's infidelity is not questioned because he is a man, and the patriarchal society does not have a problem with his behaviour. Such double standards in the treatment of women and men are prevalent in some authors of Zulu literary texts who still subscribe to the idea of male domination over their womenfolk (cf. Mbhele \& Ntuli 1988).

Hickman (1989) makes the point that women are commonly described in terms of objects, or in association with food. She believes that this association is aimed at acculturating women in relation to kitchen matters.

The patriarchal ideology that a woman should be in the kitchen, because that is where she is 'supposed' to be, is archaic and sexist, according to feminists (Hickman 1989:65). There is nothing intrinsic in women's bodies that associates them with the kitchen. Women should be wherever they want to be because they are equally as competent as men are. Women have proven their worth and abilities and that they have the power to face any challenges that come their way.

Freud (1992) argues that men use psychology to infantilise women in order to oppress them. Men do this by first gaining their confidence before seducing them, which may ultimately lead to sexual intimacy. An example of this would be the way a man might refer to his girlfriend, wife or lover as ingane yami [literally, 'my baby'], never considering her real age. One may argue that some women like to be called 'my baby' because it makes them feel younger, attractive, cared for and so on.

The author uses Tholakele and Pamella (the lesbian who is the mastermind behind the drug dealing) to problematise the myth of a 'problem free' lesbian relationship in this novel. We find the same-sex relationship freedom in which Tholakele is dating Pamella. Conversely, Tholakele is also dating Bhekani. The author says (Zulu 2006):

Nangu uTholakele esencela amabele ale ntombazane yomlungu. Nayo ayimyekile uTholakele. Ilokhu imcumbaza wona amabele. Izandla izigijimisa emhlane wonke. [Here is Tholakele sucking this White woman's breasts. This woman is also doing the same. This woman keeps on touching Tholakele's breasts. Her hands are all over her back.] (p. 24)

In many democratic and progressive countries, the union between partners of the same sex is legalised. This legalisation therefore challenges societies who are still patriarchal apropos of changing their mindset about same-sex relationship. Sossou (2002) believes that women need to stand together and fight this discrimination:

The educated African women and scholars therefore have a responsibility and obligation to champion the cause of fighting inequalities against all women. This could be done through organizing women's groups, social education, advocating for gender-sensitive legislation, networking locally, nationally, regionally and internationally with other women's groups and by taking collective actions aimed at drawing attention to the plights of women in general. (p. 208)

\section{Conclusion}

This article has explored some oppressive, stereotypical customs, rites and traditions prevalent in the Zulu society. It has shown how the character Tholakele searches for a new kind of identity in society. The novel Umshado portrays Tholakele's searching for a new role in society that will allow her to be free from traditional norms and restrictions. This new role will place her on the same level as men. Umshado also offers a new possibility to a woman's question on marriage. Why marriage? What kind of marriage do I want? Tholakele seems to be interested in male companionship which necessarily results in sexual intercourse. Her behaviour poses a number of questions according to patriarchal stereotypes: Is sexual freedom enough to procure happiness? Is it not that a woman keeps giving of herself without any tangible returns, thus succumbing to a new form of sexual slavery? How far is Tholakele's supposed freedom from promiscuity? Would motherhood be a form of entrapment or the real crowning glory of a woman's life? Is society prepared to accept this sort of behaviour by Tholakele? Most probably 'not', in a patriarchal society.

From a patriarchal point of view, Tholakele's behaviour is unacceptable. The character portrayal of Tholakele demonstrates a patriarchal stereotyping on the part of the author. Tholakele's search for sexual freedom and independence is judged negatively because she is a woman. The author firmly supports the traditional morality in this novel by the choice of language she uses, which reinforces the traditional value system, that is, a woman cannot play around with her life-giving faculty. From a patriarchal point of view, women such as Tholakele are beautiful figures that are, however, rotten to the core.

We had anticipated that the author, Zulu, being a female, would present her female protagonist positively; however, Tholakele becomes a victim at the end of the narrative whilst fighting for her freedom and independence. She gets arrested on drug charges. Zulu's portrayal of Tholakele would have shown positivity towards women's emancipation and independence had the author portrayed her in a positive light. Given that this novel has recently been published (in 2006), we expected Zulu's portrayal of her female character to be more positive in the light of recent strides towards women's emancipation.

\section{Acknowledgements Competing interests}

The authors declare that they have no financial or personal relationships that may have inappropriately influenced them in writing this article. 


\section{Authors' contributions}

All authors contributed equally to this work.

\section{Ethical considerations}

This article followed all ethical standards for a research without direct contact with human or animal subjects.

\section{Funding information}

This research received no specific grant from any funding agency in the public, commercial or not-for-profit sectors.

\section{Data availability statement}

Data sharing is not applicable to this article as no new data were created or analysed in this study.

\section{Disclaimer}

The views and opinions expressed in this article are those of the authors and do not necessarily reflect the official policy or position of any affiliated agency of the authors.

\section{References}

Brown, C.L. \& Olson, K., 1992, Feminist criticism: Essays on theory, poetry and prose, Scarecrow Press, New York.

Butler, J., 1990, Gender trouble: Feminism and the subversion of identity, Routledge London.

Cuddon, J.A., 1991, A dictionary of literary terms and literary theory, 3rd edn., Basil Blackwell Ltd, Cambridge.

Davies, C.B. \& Graves, A.A. (eds.), 1986, Ngambika: Studies of women in African literature, Africa World Press, Trenton.

De Beauvoir, S., 1949, The second sex, transl. \& ed. H.M. Parshley, Penguin Press, New York.
Dosekun, S., 2007, 'Defending feminism in Africa', Postamble 3(1), 41-47.

Freud, S., 1992, The interpretation of dreams, Pelican Press, New York.

Fuss, D., 1989, Essentially speaking: Feminism, nature \& difference, Routledge, New York.

Gray, D.H., 2013, Beyond feminism and Islam: Gender and equality in North Africa, I.B. Tauris \& Co. Ltd, New York.

Gumede, H.S. 2018, 'Feminist discourse analysis in four selected Zulu literary texts beyond 'woman as a victim', Unpublished MA dissertation, University of KwaZuluNatal, Durban.

Gumede, H.S. \& Mathonsi, N.N., 2019, 'Feminist discourse analysis of the image of the liberated woman in un Umshado (marriage) by N Zulu', Current Writing: Text and Reception in Southern Africa 31(1), 11-20. https://doi.org/10.1080/101392 9X.2018.1547014

Hickman, M., 1989, Visions of black women in literature, Anchor Press, New York.

Hooks, B., 1991, Ain't I a woman? Black women and feminism, South End Press, Boston, MA.

Lorde, A., 1984, Sister outside. Essays and speeches, The Crossing Press, New York.

Masuku, N., 2005, 'Perceived oppression of women in Zulu folklore: A feminist critique', Unpublished D Litt et Phil thesis, University of South Africa, Pretoria.

Mbhele, N.F. \& Ntuli, D.B.Z., 1988, Ishashalazi, KwaZulu Booksellers, Pietermaritzburg.

Obbo, C., 1980, African women: Their struggle for economic independence, Zed Books, London.

Ogunyemi, C., 1985, 'Womanism: The dynamics of the contemporary black female in English', Signs: Journal of Women in Culture and Society 11(1), 15-24. https://doi. org/10.1086/494200

Peterson, V.S. \& Runyan, A., 1993, Global gender issues, Oxford Westview Press, Oxford.

Sossou, M.A., 2002, 'Widowhood practices in West Africa: The silent victims', International Journal of Social Welfare 11(3), 201-209. https://doi. org/10.1111/1468-2397.00217

Spivak, G.C., 1988, 'Can the subaltern speak?', in C. Nelson \& L. Grossberg (eds.) Marxism \& the interpretation of culture Urbana, pp. 24-28, University of Illinois Press, Champaign, IL.

Thorne, B. \& Henley, N., 1976, Language and sex: Difference \& dominance, Newbury House Publishers, New York.

Von Kapff, U., 2011, The Zulu: An A-Z of culture and traditions, Struik Travel and Heritage Publishers, Pretoria.

Young, I.M., 1990, 'Justice and the politics of difference', Journal of Social Theory $3(18), 4-15$

Zondi, N., 2013, 'The position of women in Zulu and Shona societies: The case of Uvalo Lwezinhlonzi and Nervous Conditions', Alternation 20(2), 164-182.

Zulu, N., 2006, Umshado, Afritude Publishers (Pty) Ltd, Groenkloof

Zuma, R.N., 2009, 'Feminist analysis of the representation of female and male characters in selected plays in Ishashalazi', Unpublished MA dissertation, University of KwaZulu-Natal, Durban. 